\title{
Studies on Schismatoglottideae (Araceae) of Borneo L - Schismatoglottis meriraiensis, a new limestone-obligated species with viviparous leaves
}

\author{
Peter C. Boyce ${ }^{1,3}$ and Wong Sin Yeng ${ }^{2}$ \\ ${ }^{1}$ Institute of Biodiversity and Environmental Conservation (IBEC), Universiti Malaysia Sarawak, 94300 Kota Samarahan, \\ Sarawak, Malaysia \\ ${ }^{2}$ Department of Plant Science \& Environmental Ecology, Faculty of Resource Science \& Technology, Universiti Malaysia \\ Sarawak, 94300 Kota Samarahan, Sarawak, Malaysia \\ ${ }^{3}$ Author for correspondence: phymatarum@gmail.com
}

\begin{abstract}
Schismatoglottis meriraiensis P.C.Boyce \& S.Y.Wong, is described from Bukit Merirai, an isolated forested Karst limestone outcrop on the Bintulu/Kapit border of N Central Sarawak. Additional to a suite of defining characteristics, S. meriraiensis is remarkable by possessing natural viviparous capabilities from whole, partial, and fragmentary leaves. This quality is shared with Schismatoglottis puberulipes Alderw. (expanded here to include Schismatoglottis gamoandra M. Hotta), and in a different expression (restricted to the mid-rib and terminal tubule of the blade), with Schismatoglottis hayi S.Y.Wong \& P.C.Boyce, of the Multinervia Complex, to which S. meriraiensis and S. puberulipes are here assigned.
\end{abstract}

\section{Introduction}

Bornean Araceae display a marked degree of geological obligations, of which association with Karst limestone is the best reported (see Boyce and Wong 2015 for a bibliography to date). In areas with spatially isolated limestone outcrops geological obligation is often associated with allopatric local endemism of individual species within clusters of related species (Ting et al. 2012; Wong 2010; Wong and Boyce 2011).

Here we describe a taxonomically novel locally endemic species from Bukit Merirai, an isolated forested Karst limestone outcrop on the Bintulu/Kapit border of N Central Sarawak, and most similar to two species, both limestone-restricted - S. multinervia M.Hotta (endemic to Mulu c. $200 \mathrm{~km}$ to the NE) and S. hayi S.Y.Wong \& P.C.Boyce (Niah Caves c. $120 \mathrm{~km}$ to the north) of the Multinervia Complex (Wong and Boyce 2011).

Additional to a unique suite of defining characteristics, S. meriraiensis is remarkable for possessing naturally viviparous capabilities from whole, partial, and fragmentary leaves. This quality is held in common with shale-restricted Bornean Schismatoglottis puberulipes Alderw. (here expanded to encompass Schismatoglottis gamoandra M.Hotta), and shared, in a different expression (plantlets restricted to the mid-rib and terminal tubule of the blade), with Schismatoglottis hayi. Dimensions used in the descriptions are derived from fertile (i.e. mature) plants. Seedlings will have overall smaller measurements. In verifying geological occurrences for this paper we have been much assisted by the excellent geological map of Tate (2001). 

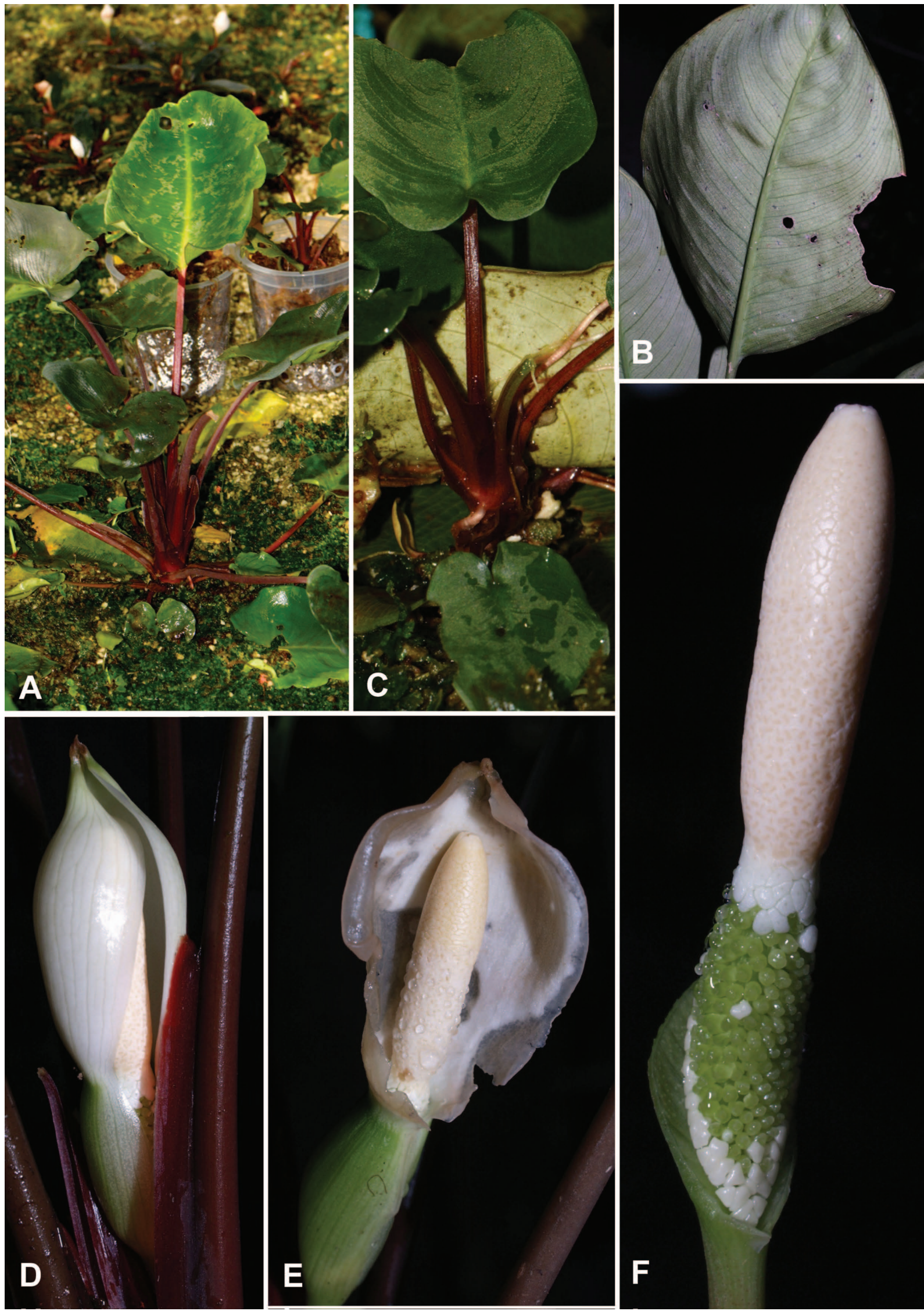

Fig. 1. Schismatoglottis meriraiensis P.C.Boyce \& S.Y.Wong. A, cultivated plant; B, leaf blade, abaxial surface; $\mathbf{C}$, adventitious plantlet arising from abaxial surface of a portion of a leaf blade; $\mathbf{D}$, inflorescence at pistillate anthesis (note inflated spathe limb); E, inflorescence at staminate anthesis (note spreading spathe limb starting to deliquesce); F, spadix at pistillate anthesis (spathe artificially removed). A-F from AR-1281. Images (C P.C. Boyce. 


\section{Taxonomy}

\section{Schismatoglottis meriraiensis P.C.Boyce \& S.Y.Wong, sp. nov.}

Diagnosis: Schismatoglottis meriraiensis is distinguished from S. puberulipes by the upper surface of the leaf blades lacking raised tessellate venation, erect (vs reflexed) petioles that are about twice as long as leaf blades (vs petioles c. $1 / 4$ length of blades), and leaves erect (not arranged in a ground-hugging rosette). Schismatoglottis meriraiensis is readily differentiated from $S$. hayi by having the staminate flowers very tightly packed (vs somewhat lax), purple-red longitudinally ridged petioles and by lacking growth points along the distal-most portion of the leaf blade under-surface midrib.

Type: MALAYSIA (Malaysian Borneo): Sarawak: Bintulu, Bukit Merirai, 02²46'26.9"N 113³9'19.8"E, S. Julia et al. S.95787, July 2005, (holo: SAR!; iso: SAR - spirit preserved!).

Small herb to c. $20 \mathrm{~cm}$ tall, but mostly half this, vegetative tissues very weakly aromatic (terpenoids). Stem condensed, hypogeal, rather stout, c. $1 \mathrm{~cm}$ diam. Leaves c. 10 together; petiole 3-14 cm long, rather slender, D-shaped in cross-section, stiff, longitudinally weakly ridged, red-purple, sheathing in the lower $1 / 3-2 / 5$ (sometimes sheathing for the entire length in the leaf below an inflorescence); wings of sheath almost fully attached except for a blunt apical free portion c. $5 \mathrm{~mm}$ long, membranous, spreading, sometimes somewhat crisped, glabrous; blade oblong-cordate to oblong-ovoid, $8-13 \mathrm{~cm}$ long, $3.2-5.5 \mathrm{~cm}$ wide, very dark green semi glossy adaxially, noticeably paler abaxially, base narrowly but distinctly cordate with rounded posterior lobes $1-2 \mathrm{~cm}$ long, tip obtuse, ultimately briefly rostrate; midrib abaxially prominent, adaxially slightly sunken; primary lateral veins $11-12$ on each side of the midrib, alternating with lesser interprimaries, both diverging at $70^{\circ}$, then rather sharply acropetally deflected before reaching the margin, adaxially somewhat prominent near the midrib; secondary venation arising from both the midrib and the bases of the primary veins, fine, abaxially slightly darker than surrounding tissue; tertiary venation forming a faint tessellate reticulum abaxially. Inflorescence solitary, subtended by a strongly 2-keeled stout red-purple prophyll; peduncle terete, very weakly longitudinally ridged, tinged red-purple where exposed, otherwise whitish. Spathe c. $4.5 \mathrm{~cm}$ long; lower spathe ovoid, c. $1.75 \mathrm{~cm}$ long, $1.3 \mathrm{~cm}$ wide, differentiated from the limb by a distinct constriction, glossy medium green with slightly darker longitudinal veining; spathe limb broadly ovate, tip apiculate, initially inflated and glossy white at onset of pistillate anthesis, then gaping and rapidly deliquescing above constriction. Spadix c. $4 \mathrm{~cm}$ long, sessile, pistillate flower zone somewhat conic, strongly obliquely attached to spathe/peduncle, dorsally c. $1 \mathrm{~cm}$ long, ventrally c. $1.5 \mathrm{~cm}$ long; pistils slightly lax, ellipsoid-globose, c. $1 \mathrm{~mm}$ diam., bright green; stigma sub-sessile, button-like, slightly more than half diameter of ovary, papillate, producing a conspicuous droplet at pistillate anthesis; sub-pistillar staminodes confined to a single row and a few scattered individuals around the base of the pistillate zone, tongue-shaped with the head triangular to rhomboidal, c. $1 \mathrm{~mm}$ wide, glossy white; sterile interstice c. $4 \mathrm{~mm}$ long, slightly narrower than top of pistillate zone, and base of staminate zone, clothed with rhomboidal staminodes, these c. $1.5 \mathrm{~mm}$ long, $2 \mathrm{~mm}$ wide at the tip, glossy white; staminate flower zone obconoid, c. $1.3 \mathrm{~cm}$ long, basally c. $4 \mathrm{~mm}$ diam., apically c. $6 \mathrm{~mm}$ diam., ivory; stamens very crowded, with individual flowers hardly discernible, c. $0.5 \mathrm{~mm}$ diam., truncate; appendix rather broadly ellipsoid, blunttipped, isodiametric with staminate zone, c. $1 \mathrm{~cm}$ long, $6 \mathrm{~mm}$ wide, ivory; appendix staminodes irregularly polygonal more or less flat-topped c. $0.7 \mathrm{~mm}$ diam. Fruiting spathe, fruits, and seeds not observed. Fig. 1.

Distribution and Habitat: Schismatoglottis meriraiensis is known only from the Type locality of Bukit Merirai, where it is highly localized. At Merirari it grows on shady ledges and in humus-filled pockets along the bases of forested limestone at elevations of c. $95 \mathrm{~m}$.

Etymology: The specific epithet is combined from Latin, ensis, meaning 'from', and the known locality of Merirari, hence the Schismatoglottis from Merirari.

Notes: Schismatoglottis meriraiensis falls uncontroversially in the Schismatoglottis Multinervia Complex (Wong and Boyce 2011) by the combination of vegetative tissues aromatic (terpenoids) when crushed, a fully adnate petiolar sheath, a strongly hourglass-shaped spadix, and by the 1-2 rows of large staminodes in at the junction of the pistillate zone with the spathe. Spathe limb senescence mechanics, however, of S. meriraiensis differs from that of S. multinervia and S. hayi, the only two species until now assigned to the Multinerva Complex, by not darkening prior to staminate anthesis and by the limb deliquescing, not splitting into recurving strips (compare Figs $1 \mathrm{E}$ and 2D, 2E and 3C). However, morphologically S. puberulipes clearly belongs to the Multinervia Complex, and has a spathe limb which deliquesces (Fig. 4G) in much the same manner as that of S. merirariensis.

Production of adventitious plantlets arises in S. meriraiensis and S. puberulipes from any portions of damaged leaves (Figs $1 \mathrm{C}, 4 \mathrm{D}$ ), whereas in S. hayi plantlets only arise from the distal-most portion of the mid-rib on the leaf blade undersurface (Fig. 2B). To date plantlet production has not been observed in wild S. multiflora, although artificial removal of leaf blades enables propagation from induced plantlets arising along the mid-veins. 


\section{The Schismatoglottis Multinervia Complex}

The Multinervia Complex now consists of the following four species:

1. Schismatoglottis hayi S.Y.Wong \& P.C.Boyce, Acta Phytotaxonomica et Geobotanica 60(3): 135-137, Fig. 2 (2011).

Type: Malaysia (Malaysian Borneo): Sarawak: Miri, Niah National Park, Batu Niah, A. Hay \& al. 93695 Feb 1994, ex Cult. RBG Sydney, Acc. No. 940520 sub. C. Herscovitch s.n. (holo: K!; iso: KEP!, L!, NSW, SAR!, US!). Fig. 2.

Schismatoglottis puberulipes sensu A. Hay \& Yuzammi, Telopea 9(1): 77-79, Fig. 9 (2000), descr. p. maj. p. excl. typ. non Aldwer. (1922).

2. Schismatoglottis meriraiensis P.C.Boyce \& S.Y.Wong, sp. nov. Fig. 1.

3. Schismatoglottis multinervia M.Hotta, Memoirs of the College of Science, University of Kyoto, ser. B, 32 (1966) 237, Fig. 6G-N; A. Hay and Yuzammi, Telopea 9(1): 72-73 (2000); S.Y.Wong \& P.C.Boyce, Acta Phytotaxonomica et Geobotanica 60(3): 132-135, Fig. 1 (2011).

Type: Malaysia (Malaysian Borneo): Sarawak: Marudi, at foot of Gunung Mulu, along Sg. Payau, M. Hotta 15297, 22 Mar 1964 (holo KYO!). Fig. 3.

4. Schismatoglottis puberulipes Alderw., Bull. Jard. Bot. Buitenzorg III, 4: 200 (1922).

Type: 'Borneo', Cult. Hort. Bogor, XI.B.X.118, C.R.W.K. van Alderwerelt van Rosenburgh 286 (lecto: BOKR! + BO spirit!, lectotype selected by Hay \& Yuzammi 2000). Fig 4

Schismatoglottis gamoandra M.Hotta, Memoirs of the College of Science, University of Kyoto, ser. B, 32: 237, Fig. 7A-G (1966), A. Hay and Yuzammi, Telopea 9(1): 123-124 (2000); P.C. Boyce, Sarawak Museum Journal 66 (87, n.s.):350-352, Pl. VIII (2009), syn. nov.

Type: Malaysia (Malaysian Borneo): Sarawak: Bintulu ('4th Divn'), along Sg. Latai, small branch of Ulu Sg. Kakus, M. Hirano \& M. Hotta 817, 7 Nov 1963 (holo: KYO!).

Notes: Alderwerelt's Schismatoglottis puberulipes is without doubt identical with Hotta's later S. gamoandra, and has nomenclatural priority (Alderwerelt 1922 vs Hotta 1966), notwithstanding that S. puberulipes is established upon fragmentary (but nonetheless identifiable) herbarium material from a cultivated plant of imprecise origin.

\section{Key to the Schismatoglottis Multinervia Complex}

1a. Spathe limb darkening prior to staminate anthesis, splitting into recurving strips during staminate anthesis; staminate flowers lax. ... 2

1b. Spathe limb not darkening prior to staminate anthesis, deliquescing during staminate anthesis; staminate flowers very densely packed 3

2a. Leaf blade broadly ovate, up to $15 \mathrm{~cm}$ long, $10 \mathrm{~cm}$ wide, abaxially glaucescent, with tertiary venation forming a rather indistinct tessellate reticulum, never forming adventitious plantlets; spadix with interstice staminodes short, mushroom-shaped. Lithophytic on limestone, rarely terrestrial on clay but even then limestone associated, Gunung Mulu National Park, Sarawak S. multinervia

2b. Leaf blade oblong-lanceolate, $8-14 \mathrm{~cm}$ long, $3.2-5.5 \mathrm{~cm}$ wide, abaxially green with tertiary venation forming a conspicuous tessellate reticulum, often with adventitious plants present; spadix with interstice staminodes conspicuously elongate-cuneate, c. $3.5 \mathrm{~mm}$ long. Lithophytic on limestone, Niah National Park, Sarawak S. hayi

3a. Leaves in a ground-hugging rosette; tertiary venation adaxially forming a conspicuous raised tessellate reticulum. On shales and shale-derived clays in the Rejang Basin and adjacent N Kalimantan S. puberulipes

3b. Leaves erect; tertiary venation adaxially obscure. Lithophytic on limestone, Bukit Merirai 


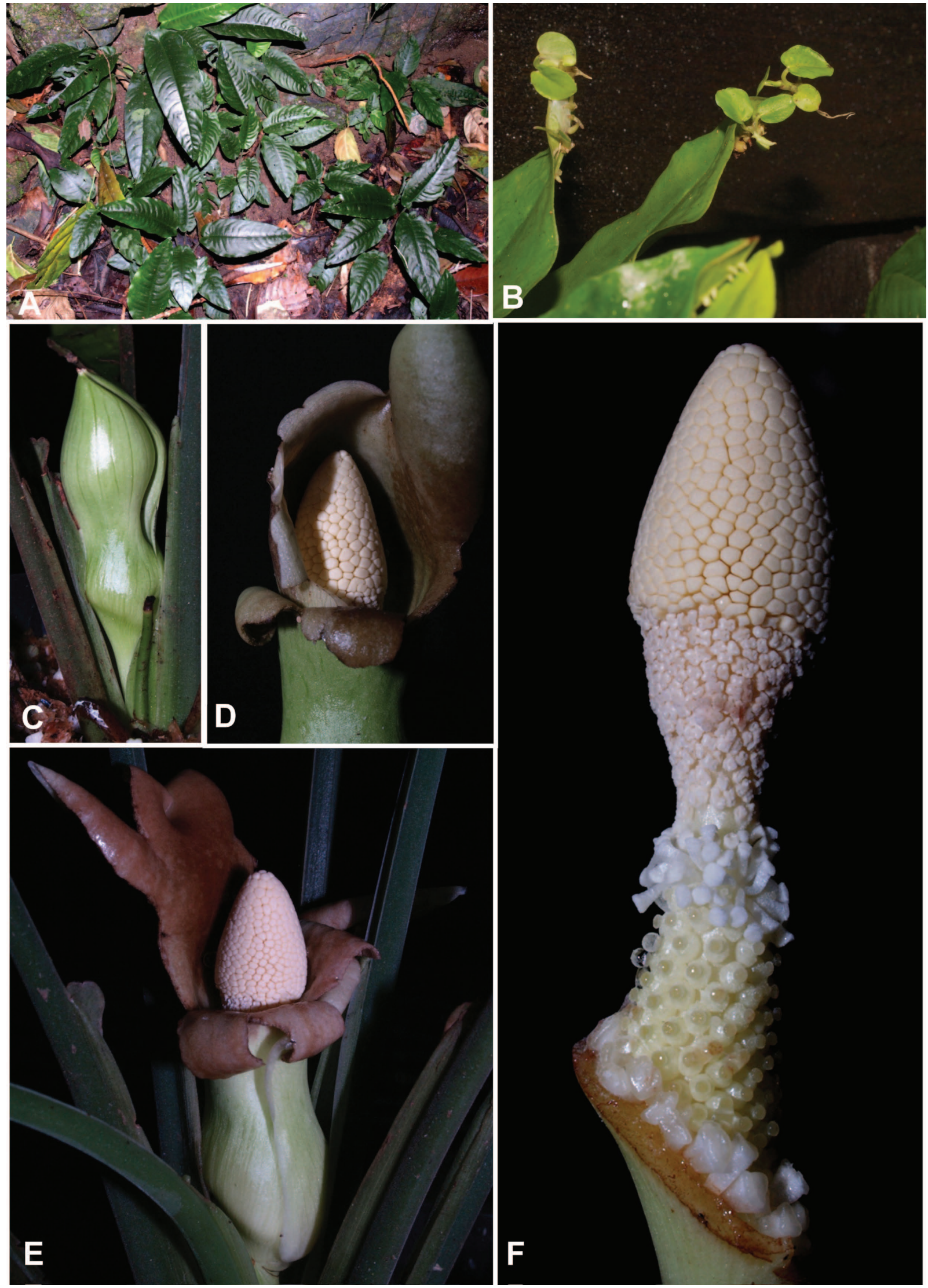

Fig. 2. Schismatoglottis hayi S.Y.Wong \& P.C.Boyce. A, plants in habitat; $\mathbf{B}$, adventitious plantlets on the tip of the leaf blade; C, inflorescence just prior to anthesis; $\mathbf{D}$, inflorescence at onset of pistillate anthesis (note that the spathe limb had opened, darkened, and begun to split); $\mathbf{E}$, inflorescence at male anthesis (the spathe is beginning to deliquesce and turn glossy, note the clearly visible pubescent petioles); F, spadix at staminate anthesis with the spathe artificially removed (note that the interstice staminodes are long and have flat tops, the distal part of the staminate zone is narrower than the base of the appendix, and that the appendix is pointed). A-F from AR-1880. Images () P.C. Boyce. 


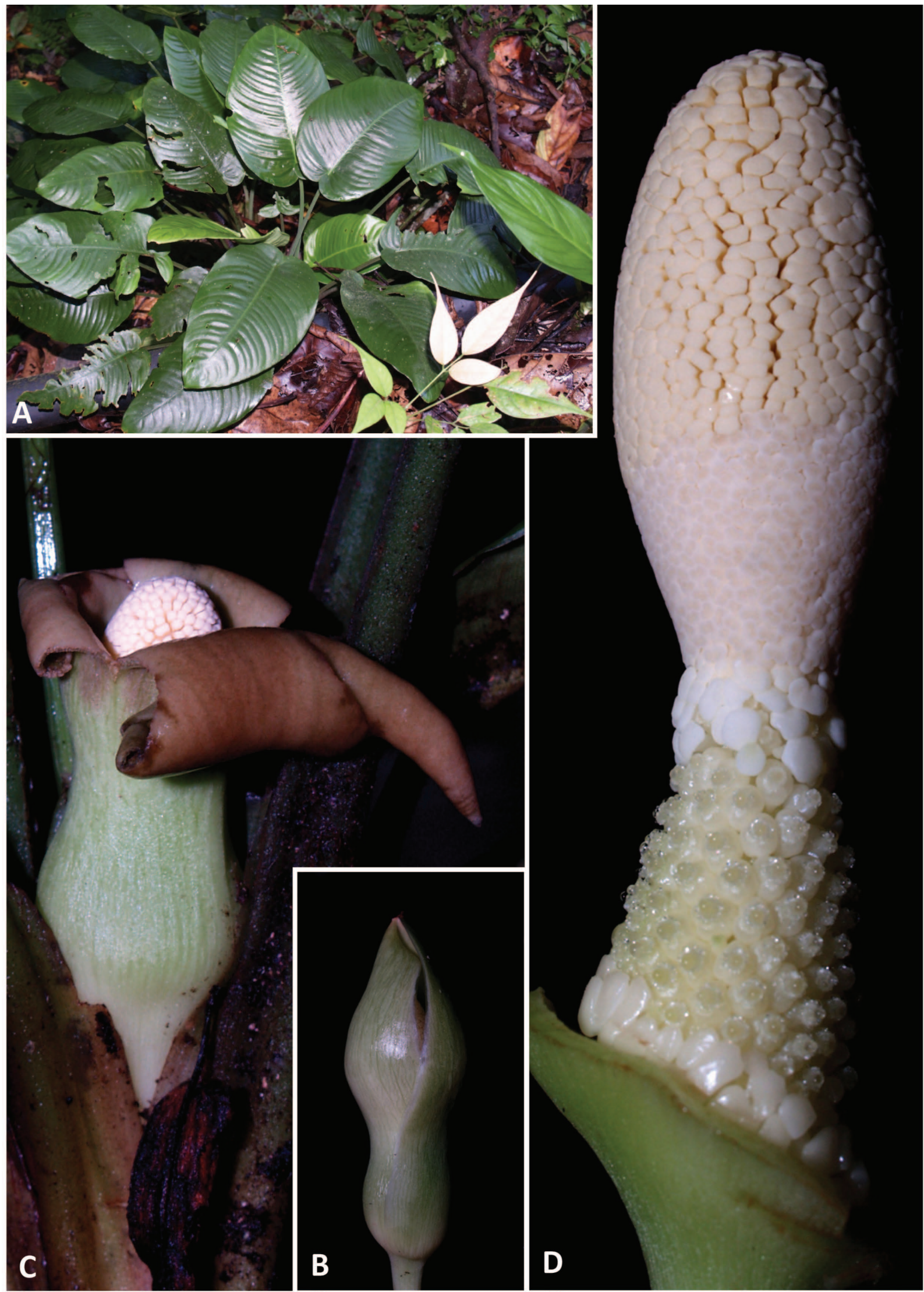

Fig. 3. Schismatoglottis multinervia M.Hotta. A, plants in habitat; B, inflorescence at onset pistillate anthesis (note the small gap that is created by the expansion of the spathe limb); $\mathbf{C}$, inflorescence at onset of staminate anthesis, the spathe limb has expanded and split longitudinally, at the same time darkening, and the pubescent petiole is clearly visible; $\mathbf{D}$, spadix at pistillate anthesis with the spathe artificially removed (note that the interstice staminodes are short and have rounded tops, the distal part of the staminate zone is the same diameter at the base of the appendix, and the appendix is blunt). A-D from AR-1932. Images (C) P.C. Boyce. 

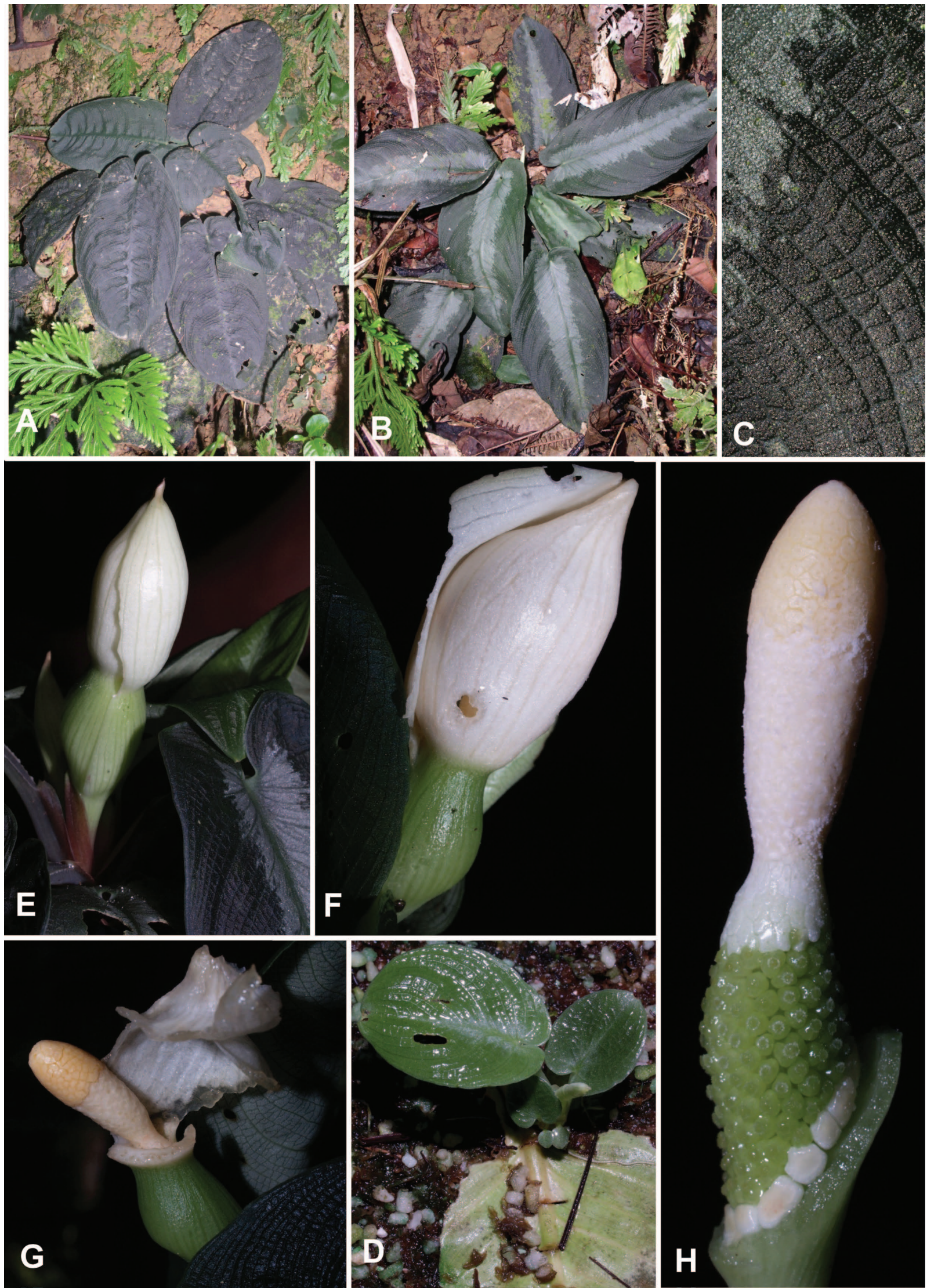

G

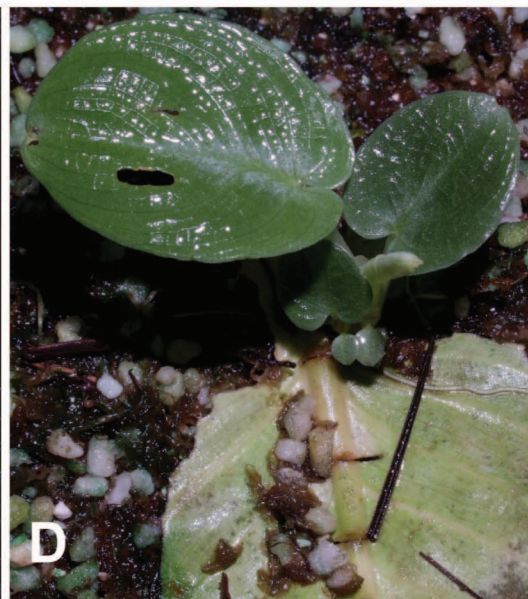

Fig. 4. Schismatoglottis puberulipes Alderw. A, B; plants in habitat to show leaf colour variation; C, detail of tessellate tertiary venation; $\mathbf{D}$, adventitious plantlet arising from a damaged portion of leaf blade; $\mathbf{E}$, inflorescence at pistillate anthesis; F, inflorescence near end of pistillate anthesis; G, inflorescence at staminate anthesis (note spathe limb deliquescing at limb/lower spathe junction); H, spadix at pistillate anthesis (note spathe artificially removed). A, B from AR-1062; C-H from AR-802. Images (C) P.C. Boyce. 


\section{Acknowledgments}

This is part of an on-going research project funded by the Ministry of Higher Education, Malaysia by the Exploratory Research Grant Scheme Vote No. NRGS/1089/2013-(03) and Fundamental Research Grant Scheme Vote No. FRGS/STWN10(01)985/2013(26). Fieldwork was most recently under Sarawak Forestry Department Permission to Conduct Research on Biological Resources - Permit No. NCCD.907, 4.4(JLD.12)51 and Park Permit No 121/2015. The collaboration and support of the Sarawak Forestry Department and the Sarawak Biodiversity Centre are gratefully acknowledged.

\section{References}

Alderwerelt van Rosenburgh, C. R. W. K. van (1922) New or noteworthy Malayan Araceae II. Bulletin du Jardin Botanique de Buitenzorg III 4: 163-229

Boyce PC, Wong SY (2015) Compendium Genera Aracearum Malesianum. Aroideana 37: 40 -177

Hay A, Yuzammi (2000) Schismatoglottideae (Araceae) in Malesia I - Schismatoglottis. Telopea 9(1): 1-177 http://dx.doi.org/10.7751/telopea20002008

Hotta M (1966) Notes on Schismatoglottidinae of Borneo. II. Memoirs of the College of Science, University of Kyoto, ser. B, 32: 223-238

Tate RB (2001) The Geology of Borneo Island [CD-ROM]. Geological Society of Malaysia, Persatuan Geologi Malaysia, Kuala Lumpur

Ting PJ, A. [et al., 2012], Wong SY, Jamliah J, Boyce PC (2012) Phylogenetic study of Schismatoglottis Nervosa Complex (Araceae: Schismatoglottideae). Gardens Bulletin Singapore 64: 211-219

Wong SY (2010) Studies on Schismatoglottideae (Araceae) of Borneo XIII: A revision of the Schismatoglottis nervosa complex. Gardens Bulletin Singapore 62: 177-209

Wong SY, Boyce PC (2011) Studies on Schismatoglottideae (Araceae) of Borneo XVI: A new species and a further new informal taxon (Multinervia Complex) of Schismatoglottis from Sarawak. Acta Phytotaxonomica et Geobotanica 60: 131-137 